\title{
Does the market react to the Australian Embassy attack in Indonesia?
}

\author{
Iman Harymawan \\ Department of Accountancy \\ Universitas Airlangga \\ Surabaya, Indonesia \\ harymawan.iman@feb.unair.ac.id.
}

\author{
Wiwiek Dianawati \\ Department of Accountancy \\ Universitas Airlangga \\ Surabaya, Indonesia \\ wiwiek.dianawati@yahoo.com.
Akbar Suryo Kusumo Baharuddin
Department of Accountancy
Universitas Airlangga
Surabaya, Indonesia
akbarskb@gmail.com

\begin{abstract}
The purpose of this study to investigate on how the market reacts to the terrorist incidents that occurred in Indonesia. To eliminate bias, this study only focuses on one event, Australian Embassy attack. This study uses an event study method to examine changes in abnormal returns after the terrorist attack. The sample of this study is all firms listed on the Indonesian Stock Exchange which indexed in LQ45. The result shows that the abnormal return of the firms is significant negative after the terrorist attacks. This indicates that firms in Indonesia experienced a negative market reaction after the terrorist attack.
\end{abstract}

Keywords—event study; terrorism; efficient market.

\section{Introduction}

Although Muslims constitute the majority population in Indonesia, does not guarantee freedom from terrorist attack. On September 9, 2004 car bomb exploded in Jalan HR Rasuna Said, Kuningan, South Jakarta, in the Australian embassy in Indonesia. The attack killed nine victims and more than 150 injured. On the day of the attack, according to our observation, IHSG (Indonesian Market Index), which opened at 790.61 prices had fallen on the price of 757.28. Then the closing price was lower than the opening price at 782.65 . Since, price is a reflection of relevant information [1], therefore, the information used by the investor may also come from non corporate actions and non economic events, for example, the terrorist attack. This study investigates whether and how the Australian embassy attack in Indonesia affects the stock market in Indonesia. Furthermore, the study also examine whether this event affect the fundamental criteria of the companies or not.

Previous studies conducted by Bradford and Robinson [2] during the Iraqi invasion of Kuwait events showed an abnormal return is negative and significant in the transportation industry during day 0 to day 5 . Then in the transportation industry more specifically, Carter and Simkins [3] found abnormal return is negative and significant in the US airline industry at the time of the September 11th attacks on the WTC and the Pentagon. More broadly Graham and Ramiah [4] conducted a study on all sectors of industry in the Japanese market using the 5 events is the United State's terrorism attack September 11th 2001, Bali bombings October 12th, 2002, Madrid March 11th 2004, London July 7th 2005 and Mumbai July 11th 2006. The results showed that of the 5 attack, September 11th provides the greatest impact on the Japanese market. Then the fifty percent still affected the industry negatively to 5 days after the event. Then Graham and Ramiah [5] with the same event do research on the Indonesian market. Results from these studies, September 11th had the most significant impact, but the Bali bombings provide a wider impact. The September 11th attack causing a negative return in four industrial sectors. While the Bali bombings affect 12 industry sectors. Research on the Indonesian market were also conducted by the Utama and Hapsari [6] using data from the terrorist attacks since 2000 until 2006. The results showed the tourism industry sectors are more affected than the other sectors.

Chen and Siems [7] stated that U.S capital market are recover sooner than other global capital market, because banking/financial that provides adequate liquidity to promote market stability and minimize panic. Then Konstantinos [8] found negative effect of terrorist activity is substantially amplified as the level of psychological effect increases. Abdullah [9] found that terrorism negatively impacts stock market returns in the long run, whereas no significant relationship between stock market returns and terrorism is estimated in the short run in Karachi Stock Exchange Pakistan. Through the empirics of the study Hobbs, Schaupp, and Gingrich [10] found that Stock returns are significantly lower for those industries predicted to be most hurt than for other industries, then stocks perform significantly worse on the days of terrorist events than on the days of military events, and Significantly lower returns follow events that occur inside the USA or where the USA was the primary target.

We investigated the reaction of the Indonesian capital market as a result of domestic terrorist attacks in which we 
aimed to have a better understanding. Most previous research using terrorism events that we consider to leave a massive influence on the market, such as September 11th that lead the NYSE and Nasdaq closed until September 17th and Bali bombings cause Indonesian Market Index (IHSG) fell to -5.53 percent [5]. So we use an event that doesn't give a massive impact on Indonesian market, the bombing of the Australian embassy. We also examined the fundamental relationship that SIZE, CASHTA, ROA, LEVERAGE and TOBINSQ with stock returns due to very rare in Indonesia. Event study methodology we use to calculate abnormal returns of each firm when the bombing of the Australian embassy. The result of abnormal return calculations, we use to answer the research hypothesis that differences in return between before and after the bombing of the Australian embassy. Then the accumulated abnormal return from day 0 to 5 after the bombing, we calculate with fundamental factors to answer hypothetical research company that is fundamentally the company is not affected by terrorist incidents.

Consistent with previous studies, we found a domestic terrorist attack impacts and the negative abnormal returns are significant [5]. Furthermore, we find no significant effect on the fundamental criteria of the companies such as: size of the firm; level of debt structure; firm performance; and firm liquidity. The results are remain insignificant even after we control of heteroskedasticity problem using robust regression. This study further enhances our understanding on how the Indonesian market reacts to the one important terrorist attack in Indonesia.

\section{II. hypothesis development}

The Efficient Market Hypothesis stated price is a reflection of information relevant [1]. Using 5 different events Graham and Ramiah [4] rediscovered negative stocks until the 5 th day after the terrorism incident on the whole industry in japan. Then with the same event Graham and Ramiah [5] found the Bali bombings a significant and significant return to 12 industry sectors in the Indonesian market. Therefore, we expect to find a significanly negative abnormal return in Indonesian market after Australian embassy bombing.

Prior research from Carter and Simkins [3] found no effect of firm size, debt and performance on market reaction due to September $11^{\text {th }}$ attacks. Following the prior findings, we predict that Australian embassy bombing have less impact than September $11^{\text {th }}$, then come to our second hypothesis that we expect fundamental aspect is not significantly affected by terrorism events.

\section{III. data and methodology}

We used a sample of companies indexed LQ45 the period on the Australian embassy bombing in September 2004. Due to data limitations, the total sample used in this study are 25 companies, consisting of 4 and 21 companies, from financial and non-financial industries, respectively. We drop 20 companies whose daily stock prices cannot be found. We obtain stock return data from Yahoo Finance along with accounting data from the Indonesian Capital Market Directory.
TABLE 1

TABLE FIRM BY INDUSTRY

\begin{tabular}{|l|l|}
\hline \multicolumn{1}{|c|}{ Selection criteria } & Total \\
\hline $\begin{array}{l}\text { Total Firm Indexed LQ45 (As of August 2004 - } \\
\text { January 2005) }\end{array}$ & 45 Firms \\
\hline Excluded: & 4 \\
\hline Financial Industry & 21 \\
\hline Non Financial Industry & 20 \\
\hline Missing Daily Stock Return & 25 Firms \\
\hline Available observation per Event & 25 Firms \\
\hline $\begin{array}{l}\text { Total number of observations (1-Event } \\
\text { Observation) }\end{array}$ \\
\hline
\end{tabular}

We used the event study methodology in our investigation. Here is the calculation of daily stock returns for each company:

$$
D R_{p t}=\frac{S R_{p, t}-S R_{p, t-1}}{S R_{p t-1}}
$$

Where $\mathrm{DR}_{\mathrm{P}, \mathrm{t}}$ is the company's daily stock returns, $\mathrm{SR}_{\mathrm{p}, \mathrm{t}}$ is a daily stock returns for businesses ${ }_{p}$ on day ${ }_{t}$, Abnormal return is calculated by the difference between the actual return and expected return by the following equation [4]:

$$
A R_{p_{i}}=D R_{p_{i}}-E\left(D R_{p_{i}}\right)
$$

Where $\mathrm{AR}_{\mathrm{p}, \mathrm{t}}$ is the abnormal return, $\mathrm{DR}_{\mathrm{P}, \mathrm{t}}$ is the company's daily stock returns. Due to the same event affects the whole company, the expected return is calculated using multivariate regression models (MVRM) [11], in which the date of the event can be entered into a dummy variable. Here is the equation:

$$
E\left(L R_{p, t}\right)=\beta_{0}+\beta_{1} r_{m_{i}, t-1}+\beta_{2} r_{n_{i} t}+\beta_{2} r_{m, t+1}+\sum_{i=1}^{D} \gamma_{p i} D_{i}+\epsilon_{p, t}
$$

The estimation period used in this study is 165 days. Consist of 92 days before and 73 days after the occurrence of the Australian embassy bombing. Where $E\left(D R_{p, t}\right)$ is day $t$ return for the equally-weighted portfolio $\mathrm{p},{ }^{T_{m, t-1}}$ is period lagged return for the market index, $\beta_{\mathrm{p}}$ are the standard marketmodel parameters for each firm/portfolio $\mathrm{p}, r_{m, t}$ is contemporaneous return for the market index, $r_{m, t+1}$ period leading return for the market index. $D_{\bar{z}}$ dummy variable equal to one during the announcement window for event $i$ for each of the events $\mathrm{D}$ under consideration, and zero otherwise, $\gamma_{p, i}$ 
measures the abnormal return for portfolio $\mathrm{p}$ generated by event $\mathrm{i}$ and $\boldsymbol{E}$ error term.

Cumulative Abnormal Return (CAR) is the total accumulated abnormal return of the test period for subsequent use in regression testing of the control variables.

$$
C A R_{\mathrm{p}, t}=\sum_{t=1}^{2} A R_{\mathrm{p}, t}
$$

\section{RESULT AND DISCUSSION}

To understand the difference between the market reaction before to after the terrorist attacks, we used a pair of 't-test . So that the research results are not affected by other events, we use the test period is five days before and after the terrorist attacks.

TABLE 2 PAIR T TEST FOR MARKET REACTION

\begin{tabular}{|c|c|c|c|c|}
\hline & Obs & $\begin{array}{c}\text { Pretest } \\
\text { Mean }\end{array}$ & $\begin{array}{c}\text { Posttest } \\
\text { Mean }\end{array}$ & p-value \\
\hline AR 5 & 25 & -0.003 & -0.015 & $0.0242 * *$ \\
\hline
\end{tabular}

$p$-values in parentheses

${ }^{*} p<0.1,{ }^{* *} p<0.05,{ }^{* * *} p<0.01$

We found a negative and significant difference between the 5 days before to five days after the embassy bombing Australia. The findings indicate that there are significant differences in the Indonesian market reaction at the time before and after the bombing of the Australian embassy. Return stocks also declined after the bombing at the Australian embassy.

Investors were also concerned to determine the impact of terrorist attacks against its market position, financial condition, the ability to generate profit companies, as well as the value of the company. For that we perform regression tests against the average abnormal return with accounting variable that represents the state.

Control variables we use are SIZE, CASHTA, ROA, LEVERAGE and TOBINSQ. Calculation (SIZE) using the natural logarithm of total assets, (CASHTA) is cash divided by total assets, (ROA) is earnings after taxes divided by total assets, (LEVERAGE) is a long-term debt divided by total equity, (TOBINSQ) is (( closing price $\mathrm{x}$ number of shares outstanding)total debt) / total assets.

The dependent variable that we use for the regression test is 6-day cumulative abnormal return (day 0 to day 5). We used the 6 day test period so that research is not biased by any other event. Here our full research model:

$\mathrm{CAR}_{\mathrm{p}}=\beta_{0}+\beta_{2} \mathrm{SIZE}_{\mathrm{p}}+\beta_{3} \mathrm{CASHTA}_{\mathrm{p}}+\beta_{4} \mathrm{ROA}_{\mathrm{p}}+$ $\beta_{5}$ LEVERAGE $_{p}+\beta_{6}$ TOBINSQ $_{i}+e_{p}$

Where;

$\mathrm{CAR}_{\mathrm{p}}=$ the cumulative abnormal returns for firm $\mathrm{j}$ over the interval from day 0 through day 5 ;

$\mathrm{B}_{\mathrm{t}} \quad=$ the parameter estimates; $\mathrm{e}_{\mathrm{p}} \quad=$ the error term for firm $\mathrm{p}$; and all other

variables as defined above

We predict there is a positive correlation between SIZE, CASHTA, ROA and TOBINSQ with stock returns because of the greater stock return produced the company's ability to control the market grew, the company has a proportion sufficient cash to avoid financial distress, the ability to generate profits rise and companies become more worth. For LEVERAGE relationship with stock returns, we suspect there is a positive relationship because the company is spurring growth and negative because companies are reducing credit risk. Below is a table of regression test results:

TABLE 3

\section{REGRESSION RESULT}

\begin{tabular}{|c|c|c|}
\hline \multirow{2}{*}{ Variables } & \multicolumn{2}{|c|}{ Australian Embassy Bombing } \\
\cline { 2 - 3 } & Expected Sign & CAR5 \\
\hline SIZE & + & -0.002 \\
\hline CASHTA & + & $(-1.20)$ \\
\hline ROA & + & -0.028 \\
\hline & + & $(-1.44)$ \\
\hline LEVERAGE & + & 0.035 \\
\hline & $+1.42)$ \\
\hline TOBINSQ & + & 0.000 \\
\hline$N$ & & -0.001 \\
\hline
\end{tabular}

$t$ statistics in parentheses

${ }^{*} p<0.1,{ }^{* *} p<0.05,{ }^{* * *} p<0.01$

According to Table 3, cumulative abnormal return (CAR) has no significant effect on the entire control variables used in this study. All fundamental companies' criteria do not show a significant association with the abnormal return. However, because our data collection represents different size, therefore, our current research model is subject to heteroscedasticity issue. To resolve this problem, we perform robustness test. Table below is the result:

TABLE 4 ROBUSTNESS REGRESSION

\begin{tabular}{|c|c|c|}
\hline \multirow{2}{*}{ Variables } & \multicolumn{2}{|c|}{ Australian Embassy Bombing } \\
\cline { 2 - 3 } & Expected Sign & CAR5 \\
\hline SIZE & + & -0.002 \\
\hline & & $(-1.28)$ \\
\hline CASHTA & + & -0.028 \\
\hline
\end{tabular}




\begin{tabular}{|c|c|c|}
\hline & & $(-1.28)$ \\
\hline ROA & + & 0.035 \\
\hline LEVERAGE & $+/-$ & $(1.66)$ \\
\hline & & 0.000 \\
\hline TOBINSQ & + & $(1.04)$ \\
\hline$N$ & & -0.001 \\
\hline
\end{tabular}

$t$ statistics in parentheses

${ }^{*} p<0.1,{ }^{* *} p<0.05,{ }^{* * *} p<0.01$

Similar to prior findings, we find no significant effect on the SIZE, CASHTA, ROA, LEVERAGE, and TOBINSQ by using robust regression. Therefore, our hypothesis fundamental aspect are not affected by terrorism effect supported by empirical evidence and also consistent with previous study there is no significant impact on fundamental aspect due to terrorist attack [3].

\section{CONCLUSIONS}

Terrorist attack affected many country including Indonesia [5]. The purpose of this study is to investigate Indonesia market reaction due to terrorist attack. Using Australian embassy bombing event, we perform empirical techniques to examine impact of Australian embassy bombing on the Indonesian market. Our results showed that there was a negative and significant return after the terrorist attacks, but the fundamental factor in this study specifically $S I Z E$, CASHTA, ROA, LEVERAGE, TOBINSQ there is no significant effect. It showed at the time of the terrorist attacks on the market reaction is only shortly panic, not to have an impact on the company's ability to control the market, the adequacy of the proportion of cash to pay short-term obligations, the company's ability to generate profits, the company's ability to maintain financial health, as well as the ability of the company to be worth the eyes of investors.

An event that we used in this study does not provide a massive impact on the market. Coverage in the media and the fear induced by the Bali bombing nor one, so that the fundamental performance has no effect. For a better understanding in future investigations, first researcher can include short term and long term risk impact after terrorism effect, second researcher can use variation days of cumulative abnormal return, third researcher focus on specific industries.

\section{References}

[1]. Fama, E.F., Efficient capital markets: A review of theory and empirical work. The journal of Finance, 1970. 25(2): p. 383-417.

[2]. Bradford, B.M. and H.D. Robison, Abnormal returns, risk, and financial statement data: The case of the Iraqi invasion of Kuwait. Journal of Economics and Business, 1997. 49(2): p. 193-204.

[3]. Carter, D.A. and B.J. Simkins, The market's reaction to unexpected, catastrophic events: the case of airline stock returns and the September 11th attacks. The Quarterly Review of Economics and Finance, 2004. 44(4): p. 539558.

[4]. Graham, M.A. and V.B. Ramiah, Global terrorism and adaptive expectations in financial markets: evidence from Japanese equity market. Research in International Business and Finance, 2012. 26(1): p. 97-119.

[5]. Ramiah, V. and M. Graham, The impact of domestic and international terrorism on equity markets: evidence from Indonesia. International Journal of Accounting \& Information Management, 2013. 21(1): p. 91-107.

[6]. Utama, C.A. and L. Hapsari, Jenis Industri, Kepemilikan Saham Asing Dan Reaksi Pasar Modal Akibat Serangan Bom Teroris. Jurnal Akuntansi dan Keuangan Indonesia, 2012. 9(2): p. 100-116.

[7]. Chen, A.H. and T.F. Siems, The effects of terrorism on global capital markets. European journal of political economy, 2004. 20(2): p. 349-366.

[8]. Drakos, K., Terrorism activity, investor sentiment, and stock returns. Review of Financial Economics, 2010. 19(3): p. 128-135.

[9]. Alam, A., Terrorism and stock market development: causality evidence from Pakistan. Journal of Financial Crime, 2012. 20(1): p. 116-128.

[10]. Hobbs, J., L.C. Schaupp, and J. Gingrich, Terrorism, militarism, and stock returns. Journal of Financial Crime, 2016. 23(1): p. 70-86.

[11]. Petry, S., Workers on the board and shareholder wealth: Evidence from a natural experiment. 2015. 